\title{
MULTI-ATTRIBUTE ANALYSIS OF ORCHARD ACCORDING TO THE INTEGRATED PRODUCTION CONCEPT
}

\author{
Aleksandar Maksimović ${ }^{1}$, Zoran Grgić2 Ferhat Ćejvanović $^{3}$
}

\begin{abstract}
Summary
Integrated fruit production (IFP) is an economical, high-quality fruit production which prioritizes ecologically acceptable means of production, which minimize side-effects aiming to increase environment conservation and human health.

Following the market demands and increasing production standards, integrated production imposes itself, which is to enable lucrativeness, market competition and ecological acceptability of agricultural products.

Introducing and implementing multi-criteria model of decision-making is based on DEXi method (multi-attribute analysis). This method makes selection of the most adequate fruit sort for initiating fruit production. This model of decision-making is based on opinions of experts from the field of integrated production. The main criterion in evaluating IFP according to DEXi and expert system are: economic, technological, ecological and socio-political.

The result of multi-criteria expert system DEXi have shown that the plum fruit sort yields the best results according to integrated production concept and can be recommended as the first planting alternative. The second alternative recommends apple while the third one recommends pear.
\end{abstract}

Key words: integrated fruit production, expert decision-making, DEXi method, fruit sort selection, plum, apple, pear.

JEL: Q10, C69.

1 Aleksandar Maksimović Ph.D. candidate, Lecturer, College of Computer Science and Business Communications eMPIRICA, Bulevara mira no. 4, Brcko district, Bosnia and Herzegovina, Phone: +387 49230 111, E-mail: a.maksimovic22@gmail.com.

2 Zoran Grgić Ph.D., Full professor, Faculty of Agriculture, University of Zagreb, Svetosimunska cesta no. 25, Zagreb, Croatia, Phone: +385 012393760 E-mail: zgrgic@agr.hr.

3 Ferhat Ćejvanović Ph.D., Associate Professor, External associate: Faculty of Economics in Tuzla, University of Tuzla, Univerzitetska Street no. 8, Tuzla, Bosnia and Herzegovina and Government of Brcko district, Bulevar mira no. 1, Brcko district, Bosnia and Herzegovina, Phone: +38735320 820, E-mail: ferhat.cejvanovic@gmail.com. 


\section{Introduction}

The territory of Bosnia and Herzegovina has favourable both natural and ecological conditions for intensive fruit production, which allows investment efficiency and competitiveness on market. Despite all of that, today Bosnia and Herzegovina has unorganized fruit production. Problems and limits with fruit production in Bosnia and Herzegovina are the following: inefficiency, inability to measure and monitor costs, lack of production documentation, levels of required knowledge both in terms of production technology and in terms of basic management principles (Galjak, Bojkovic, 2015) and market knowledge, the product placement, unwillingness to adapt in terms of changing the business processes, especially the elders. Domestic market, and especially foreign one, demands consistent quality and supply conduit, as well as certification of products. Implementation of IFP as a generally accepted system of manufacturing can contribute overcoming existing problems when it comes to fruit growing in Brcko District and region, and increase its competitiveness.

Following the market requirements and incensement of standards in terms of manufacturing, integrated manufacturing is being imposed which has to enable economic profitability, competitiveness on the market, and environmental acceptability. Integrated fruit manufacturing is defined as economical manufacturing of high-quality fruit, which gives priority to ecologically safe methods that minimalize unwanted side effects of agricultural chemical substance uses, with goal of improving environment and human health safety (Grahovac et al., 2011).

Choosing which type of fruit is the most economical to plant will be determined using multi-attribute analysis DEXi methods. It helps the user in making a decision about some complex decision problem, in which one should compare good and bad sides of different variants. With this method we'll determine the most economical fruit to plant in Bosnia and Herzegovina, by integral concept.

The main difference of DEXi method to the other multi-criteria decision analysis methods is that this method does not do transformation of linguistic values but uses „if only“ rules (Rozman et al., 2016). The result of this application is the linguistic value and not the numerical one. Due to all this, this method is in advantage to other MCDA methods because it can use various linguistic values and the end result is the same in that value by which the decision edges closer to human way of thinking.

While performing these methods in agriculture, the method that was used the most was the method of analytical hierarchical process (AHP). The examples of the usage of this method when sourcing the variety can be easily located in the following works: (Rozman et al., 2015a; Agha et al., 2012; Van Chuong, 2011; Agha, 2011; Srđević et al., 2004). As opposed to AHP method, the sourcing issues can be described as qualitative usage of non-numerical values and ,if only" rules. This paper shall use qualitative non numerical variables. Therefore, the usage of DEXi method is the logical sequence of events while determining the fruit sort selection. This method is useful for problems that are not fully specified such as the system of arable production which is the typical example of such problems (Rozman et al., 2015b; Pozderec et al., 2015; Tojnko et al., 2011). 


\section{Methodology of DEXi analysis method}

DEXi Methodology enables the description of hierarchy attributes in conceptual model and rule aggregation between the attributes which is usable with problems of real decision making. (Kontić et al., 2006). DEXi method combines the traditional multicriteria decision making methodology with the elements of expert system and machine language. (Pavlović et al., 2011). DEXi stands for Decision Expert and it's built on multi-parameter methodology of making a decision DECMAK (DECision MAKing) as well as artificial intelligence usage. DEXi is a methodology for qualitative, multicriteria decision making modelling and support (Bohanec, Rajković, 1990). Knowledge base doesn't derive from mathematical formulas, but from user's/expert's knowledge. The user is encouraged to discover „space of deciding“ by defining criteria's and qualitatively describing its values. Knowledge is presented in form of decision rules if-then. The distinctive feature of DEXi has given its ability to handle with qualitative variables and linguistically values in a function of finding the most profitable alternative of fruit planting with help of multiple criteria's such as: Economic, Political and Social, Ecological and Technological.

Financial criteria consist of investment costs, Net Present Value and Internal Rate of Return (quantitatively measured criteria). Technological criteria consists of growth technology and ability to store (which represents qualitative criteria), as well as manpower (which can be separated to family work and hired work, and can also be expressed in quantitative values). Market criteria reflect attractively for each fruit and consummation diversity (qualitative criteria). Finally, criteria of conveniently selected location shows ecological state (ground, incline, and ability of spring frost).

Instead of numerical variables, which usually represent traditionally quantitate models, DEXi uses qualitative variables whose values are, in most cases, represented by words and not numbers, such as „small“, ,,appropriate“, and „inappropriate“.

DEXi principle is made up of three stages (Bohanec, 2003):

- $\quad$ problem identification and criteria determination

- $\quad$ setting of decision-making rules (utility function definition)

- $\quad$ analysis of each alternative.

DEXi is an easy way to create and modify the criteria of wood and edit the measurement scales and decision-making rules. Data entry on variants and variants evaluation is also very simple (Bahovac, Zupan, 2006). The results of evaluation are shown in tabular form, as well as what-if analysis (Stanojevic et al., 2016). Graphical view is also applicable. Structure of the model evaluation criteria in orchard establishing, which was created using the expert system DEXi, is shown in Table 1 together with measurement scales. Values on measurement scale are sorted from worse to better. 
Table 1. Qualitative criteria structure for orchard establishment evaluation

\begin{tabular}{|c|c|}
\hline Criteria's & Qualitative value criteria - measuring scale \\
\hline Fruit planting choice & Not acceptable, acceptable, very acceptable \\
\hline +-Economical criteria & Insignificant, important, very important \\
\hline *-Financial criteria & Insignificant, important, very important \\
\hline ||*-Investment criteria & Big, medium, low \\
\hline ||*-Net present value & Negative, low, high, very high \\
\hline $\mid$ |*-Internal return rate & Negative, low, high, very high \\
\hline | + +-Profitability index & Negative, low, high, very high \\
\hline *-Economic success measurement & Insignificant, important, very important \\
\hline ||*-Cost-effectiveness & Negative, low, high, very high \\
\hline | +-Profitability & Negative, low, high, very high \\
\hline +-Marketing criterion & Insignificant, important, very important \\
\hline$*_{\text {-Selling possibility }}$ & Small, medium, large \\
\hline *-Export possibility & Small, medium, large \\
\hline +-Required promotion & Big, medium, low \\
\hline +-Socio-political criterion & Insignificant, important, very important \\
\hline *-Social criteria & Not acceptable, acceptable, very acceptable \\
\hline || *-Life standard improvement & Low, medium, high \\
\hline | *-Fruit grower's knowledge increase & Low, medium, high \\
\hline||$+-$ The habit of growing certain fruits & Unchangeable, changeable, highly variable \\
\hline |+-Political criteria & Not acceptable, acceptable, very acceptable \\
\hline *- Caring for a particular state fruit production & Non-existing, bad, good, excellent \\
\hline *- State subsidies & Non-existing, bad, good, excellent \\
\hline +-Export subsidies & Non-existing, bad, good, excellent \\
\hline +-Technical criterion & Insignificant, important, very important \\
\hline *-Irrigation and drainage & Big, medium, low \\
\hline *-Growth technology & Big, medium, low \\
\hline *-Manpower & Big, medium, low \\
\hline *-Mechanical support & Big, medium, low \\
\hline +-Storing & Big, medium, low \\
\hline +-Ecological criterion & Insignificant, important, very important \\
\hline *-Pollution impact & Insignificant, important, very important \\
\hline |*-Water & Big, medium, low \\
\hline *-Ground & Big, medium, low \\
\hline +-Air & Big, medium, low \\
\hline *-Manure usage & Insignificant, important, very important \\
\hline |*-Manure & Insignificant, important, very important \\
\hline |+-Fertilizers & High level, medium level, low level \\
\hline *-Pesticides usage & High level, medium level, low level \\
\hline +-Water potentials usage & High level, medium level, low level \\
\hline
\end{tabular}

Source: Authors'research

Step 1 Problem structure

Structuring the problem occurs in a manner that agricultural entrepreneur wants to establish an orchard. It's necessary to make a decision for specific fruit sort on chosen location. 
Step 2 Fruit sort identification

Identification consists of three fruit sorts who have the highest representation in Bosnia $\&$ Herzegovina and Brcko district, and those are plum, apple and pear.

Step 3 Financial cost-benefit analysis for each fruit sort

For each fruit sort is carried out a cost-benefit analysis and calculation of basic financial indices net present value and internal return rate for each fruit sort, as already demonstrated in earlier work.

Step 4 Identification of goals and criteria's

Various techniques can be used in order to identify goals and criteria's for analysis. Multi-criteria way of decision making can be good enough to identify goals and criteria's that'll be of use in project evaluation. Multi-criteria decision making treats the problem of a hierarchical structure of evaluation (egg, analysis hierarchy process) decision tree. DEXi methodology is based on criteria formation in decision making tree. For the purposes of analysis of orchard establishment tree of criteria has been developed

Step 5 Utility function definition (rules of decision making) and analysis execution

When each criterion is marked with its value base (stock), access to decision making classification is being done. DEXi methodology uses qualitative values for alternative evaluation decision making. Whole project's utility function consists of partial utility functions which are defined for aggregated criteria's. These utility functions are defined by the decision making rules.

Based on defined rules of decision making we can calculate relative weight of each criterion, which is (in DEXi system) done via method of multiple regressions or machine learning method - in formativeness. In regression every rule-making can be presented as a series of point which are approximated with hyper plane. This means that every qualitative parameter in any rule-making is given an original number through approximation regression equation $\mathrm{y}=\mathrm{a}_{\mathrm{o}}+\mathrm{a}_{1} \mathrm{x}_{1}+\ldots+\mathrm{a}_{\mathrm{n}} \mathrm{x}_{\mathrm{n}}$. Parameter $\mathrm{a}_{\mathrm{o}}$ can be omitted and relative weights are calculated via:

$$
w_{i}=\frac{100 a_{i}}{\sum_{j=1}^{n} a_{j}} ; i=1,2, \ldots, n
$$

Where: $\mathrm{w}_{\mathrm{i}}$ stands for relative weight of criteria i.

A different way to calculate relative weights of each criterion is with in formativeness method, based on formula (Ćejvanović, 2007):

$-\sum p_{i} \log _{2} p_{i}$

Where: $p_{i}$ stands for the like hood of events $i$. 
Once the decision-making rules have been established analyst sets qualitative values for each criterion, responding to every alternative solution. After the entered values, DEXi carries out analyses for each alternative solution. Automatic ,what-if, analysis can be carried out (observing any changes in various „,model input parameters“ and their influence on evaluated values)

\section{Results}

Orchards establishment rating (utility function) is based on four criteria's: financial, technological, socio-political, and ecological. Relative weight of each criteria isn't equal for all four criteria's and it has different percentage values. Financial criterion is $29 \%$, technological $9 \%$, location convenience criterion is $31 \%$ and market criterion is $31 \%$ of total relative weight.

Following image presents the criterion results - attributes for three fruit sorts.

Figure 1. Attributes result for apple plum pear

\begin{tabular}{|c|c|c|c|}
\hline Attribute & Plum & Pear & Apple \\
\hline Fruit planting choice & Very acceptable & Very acceptable & Very acceptable \\
\hline Economical criteria & Very important & Very important & Very important \\
\hline Financial criteria & Very important & Important & Very important \\
\hline -Investment criteria & Low & Medium & Medium \\
\hline Net present value & High & Low & High \\
\hline -Internal return rate & Very high & High & Very high \\
\hline Profitability index & Very high & Low & High \\
\hline Economic success measurement & Very important & Important & Very important \\
\hline -Cost-effectiveness & High & Low & Very high \\
\hline LProfitability & Very high & High & High \\
\hline Marketing criterion & Important & Very important & Important \\
\hline -Selling possibility & Medium & Large & Medium \\
\hline Export possibility & Medium & Large & Medium \\
\hline$L_{\text {Required promotion }}$ & Low & Medium & Medium \\
\hline Socio-politi & Very important & Important & Important \\
\hline -Socia & Very acceptable & Acceptable & Acceptable \\
\hline -Life standard improvement & High & Low & Medium \\
\hline Fruit grower's knowledge increasement & High & Medium & Low \\
\hline -The habit of growing certain fruits & Highly variable & Changeable & Changeable \\
\hline Political criteria & Acceptable & Acceptable & Acceptable \\
\hline -Caring for a particular state fruit production & Good & Good & Good \\
\hline -State subsidies & Good & Bad & Bad \\
\hline LExport subsidies & Non-existing & Non-existing & Non-existing \\
\hline -Technical criterion & Important & Insignificant & Important \\
\hline ainage & Medium & Big & Medium \\
\hline -Growth technology & Medium & Big & Medium \\
\hline -Manpower & Medium & Medium & Medium \\
\hline -Mechanical support & Medium & Medium & Medium \\
\hline -Storing & Short run & Short run & Long run \\
\hline Ecological criterion & Very important & Very important & Very important \\
\hline -Pollution impact & Very important & Importe & Very important \\
\hline -Water & Medium & Low & Low \\
\hline -Ground & Low & Medium & Low \\
\hline -Air & Medium & Medium & Medium \\
\hline Manure usage & Very important & Important & Important \\
\hline & Very important & Important & Important \\
\hline LFertilizers & Low level & Medium level & Medium level \\
\hline -Pesticides usage & Medium level & Low level & Medium level \\
\hline -Water potentials us & Medium level & Medium level & Medium level \\
\hline
\end{tabular}

Source: Authors'research 
Based on analysis of experts and by DEXi method, weaknesses and strengths for each fruit sort were singled out:

Figure 2. Strengths and weaknesses of apple attribute

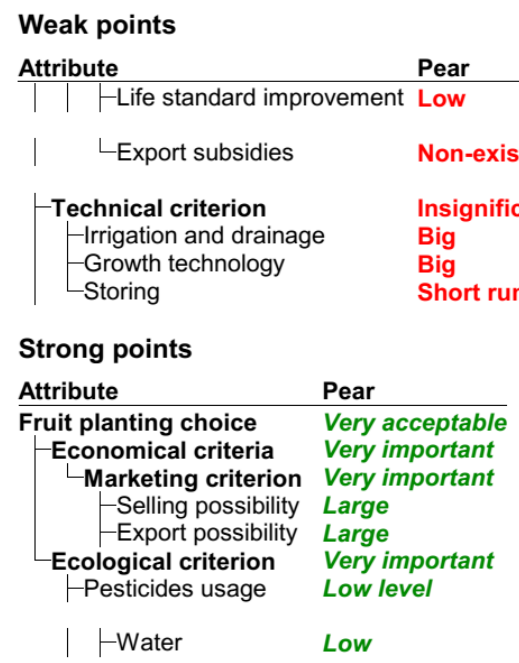

Weak points

Attribute | | Fruit grower's knowledge increasement Low

\section{Weak points}

Attribute Plum

| Lexport subsidies Non-existing

| LStoring Short run

\section{Strong points}

Attribute Plum

\begin{tabular}{|ll}
\hline Fruit planting choice & Very acceptable \\
Economical criteria & Very important \\
\hline Financial criteria & Very important \\
- Investment criteria & Low \\
- Internal return rate & Very high \\
Profitability index & Very high \\
Economic success measurement & Very important \\
LProfitability & Very high \\
-Socio-political criterion & Very important \\
-Social criteria & Very acceptable \\
-Life standard improvement & High \\
- Fruit grower's knowledge increasement & High \\
-The habit of growing certain fruits & Highly variable \\
Ecological criterion & Very important \\
-Pollution impact & Very important \\
- Ground & Low \\
Manure usage & Very important \\
-Manure & Very important \\
Fertilizers & Low level
\end{tabular}

Low level

| LExport subsidies Non-existing

\section{Strong points}

\begin{tabular}{|c|c|}
\hline Attribute & Apple \\
\hline $\begin{array}{l}\text { Fruit planting choice } \\
\text {-Economical criteria } \\
\text { - Financial criteria } \\
\text {-Internal return rate } \\
\text { Economic success measurement } \\
\text {-Cost-effectiveness } \\
\text { Ecological criterion } \\
\text { - Pollution impact } \\
\mid \text {-Water } \\
\text { - Ground }\end{array}$ & $\begin{array}{l}\text { Very acceptable } \\
\text { Very important } \\
\text { Very important } \\
\text { Very high } \\
\text { Very important } \\
\text { Very high } \\
\text { Very important } \\
\text { Very important } \\
\text { Low } \\
\text { Low }\end{array}$ \\
\hline Storing & Long run \\
\hline
\end{tabular}

Source: Authors'research

Image shows us that export subvention doesn't exist for apple, plum and pear, and that plum has the most positive attributes compared to other two fruit sorts. Apple has more positive attributes than pear. On the basis of above we can say that the top ranked fruit sort is plum, followed by apple, and then pear (based on expert's rating and DEXi method). This statement could be set aside as recommendation for the future 
establishment of orchards. The following image shows the disposition and weight criteria for each fruit sort.

Figure 3. Graphical presentations of results with the DEXi expert system

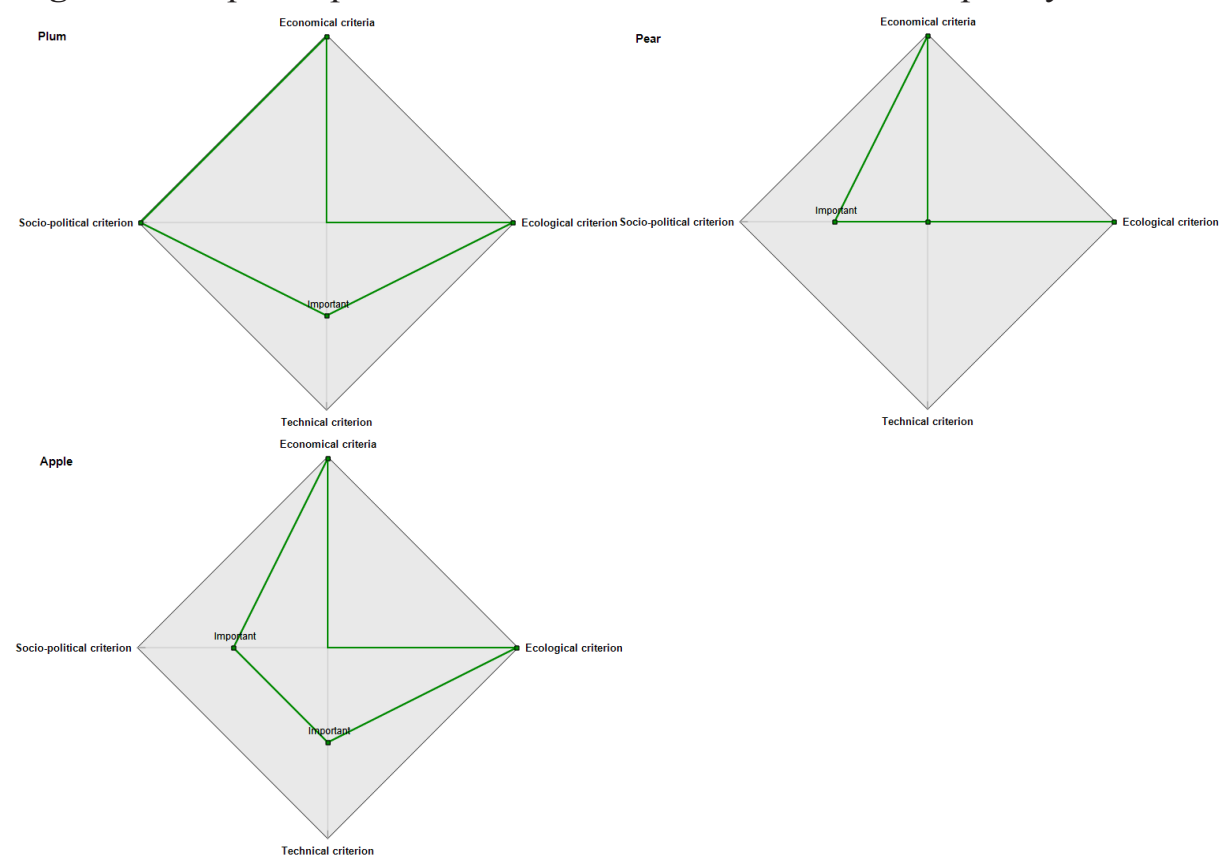

Source: Authors'research

Based on presented analysis, the best indicator on economic criteria is the plum and apple, while the pear shows lower results. (More about this work is discussed in economic analysis in the context of this work). Socio-political criterion, top predispositions has plum due to often incentive by the government of Brcko District to this fruit sort, next is apple, while pear shows 'not so significant' importance in this criteria compared to plum. Technical criterion implies that the apple and plum has significant requests towards the growth technology while with pear some difficulties occur and it shows the poorest results. The basis of this statement is small number of pear orchards on territory of Brcko District and therefore the technical requirements for this type of production are higher than for the apple and plum production. Ecological criteria shows moderation in all three fruits, though the pear's potential ground contamination is lower comparing to apple and plum, due to lower number of treatments.

\section{Conclusions}

Bosnia and Herzegovina has favourable natural conditions for fruit production development. However, Bosnia and Herzegovina does not achieve satisfactory results in fruit production in relation to its conditions. Problems and limits in fruit production to Bosnia and Herzegovina are: non-profitability, measurement inability and cost monitoring, lack of knowledge in terms of basic management principles 
and knowledge of market. Implementation of IFP, as a generally accepted system of production, can contribute to overcoming the existing problems with fruit production in Bosnia and Herzegovina, thus increasing its competitiveness. This paper considers the alternatives of fruit sort growing, i.e. which fruit sort is the most profitable, using the multi-criteria expert analysis DEXi. Following criteria were considered through this method: economical, socio-political, ecological and technological. As a result of research with DEXi method it can be concluded that plum shows the best results, therefore it could be recommended as a primary alternative in selection of fruit sort. The second recommended alternative is the apple. Bosnia and Herzegovina, through its amenable ministries of agriculture, should especially emphasize the plum and apple fruit production.

\section{References}

1. Agha, S. R. (2011): A multi-criteria crop planning model based on the "resistive economy" characterizing the situation in Gaza Strip. 8th International conference on Islamic economy and finance", Doha, Qatar, pp. 1-22.

2. Agha, S. R., Latifa, G.N., Nassar, H.A., Shehada, R.Y., (2012): Multi Criteria Governmental Crop Planning Problem: an Analytic Hierarchy Approach. Management, Vol. 2, No. 4, pp. 96-105.

3. Bohanec, M. (2003): Decision Support, Data Mining and Decision Support. Academic Publishers, London.

4. Bohanec, M., Rajkovič, V. (1990): DEX: An Expert System Shell for Decision Support. Sistemica. Lima, Vol. 1, No. 1, pp. 145-158.

5. Bohanec, M., Rajkovič, V. (1999): Multi-Attribute Decision Modelling: Industrial Applications of DEX. Informatica, No. 23, pp. 487-491.

6. Bohanec, M., Zupan, B. (2004): A function-decomposition method for development of hierarchical multi-attribute decision models. Decision Support Systems, No. 36, pp. 215-233.

7. Ćejvanović, F. (2007): Ekonomska analiza integralne proizvodnje voća. Institut za ekonomiku poljoprivrede, Beograd.

8. Galjak, I., Bojkovic, C. (2015): Istorijski aspekti razvoja trzista kapitala $i$ korporativnog upravljanja, Oditor, Belgrade, Serbia, no. 10, pp. 10-16.

9. Grahovac, M., Inđić, D., Tanović, B., Lazić, S., Vuković, S., Hrustić, J. Gvozdenac S. (2011): Integralna zaštita jabuka od prouzrokovača truleži u skladištima. Pesticidi i fitomedicina, Vol. 26, No. 4, pp. 289-299.

10. Kontić B, Bohanec M, Urbančič T, (2006) An experiment in participative environmental decision making. The Environmentalist, Vol. 26, No. 1, pp. 5-15.

11. Kontić, B., Bohanec M. (1998): Izbor lokacije za odlagališče NSRAO, Prikaz uporabe odločitvenega pristopa DECMAK in računalniškega programa DEX, Institut Jožef Stefan.

12. Pavlović, M., Cerenaka, A., Pavlović, V., Rozman, Č., Pažek, K., Bohanec, M. (2011): Development of DEX-HOP multi-attribute decision model for preliminary hop hybrids assessment. Computers and Electronics in Agriculture, Vol. 75, No. 1, pp. 
181-189.

13. Pozderec, S., Bavec, M., Rozman, Č., Vinčec, J., Pažek, K. (2015): MultiCriteria Assessment of Vegetable Production Business Alternatives. Organizacija, Vol. 48, No. 3, pp. 203-213.

14. Rozman, Č., Grgić, Z., Maksimović, A., Ćejvanović, F., Puška, A., Šakić Bobić, B. (2016): Multiple-criteria approach of evaluation of milk farm models in Bosnia and Herzegovina. Mljekarstvo, Vol. 66, No. 3, pp. 206-214.

15. Rozman, Č., Hühner, M., Kolenko, M., Tojnko, S., Unuk, T., Pažek, K. (2015a): Apple Variety Assessment with Analytical Hierarchy Process. Erwerbs-Obstbau, Vol. 57, No. 2, pp. 97-104.

16. Rozman, Č., Pažek, K., Pavlovič, V., Bohanec, M., Pavlovič, M. (2015b): Application of Multi Criteria DEX Model in Hop Breeding. 13th International Symposium on Operational Research SOR'15, pp. 40-44.

17. Srdjević, B., Srdjević, Z., Kolarov, V. (2004): Group evaluation of walnut cultivars as a multicriterion decision-making process. In CIGR International Conference, Beijing, China, pp. 11-14.

18. Stanojevic, Lj., Trivan, D., Bakreski, O. (2016): Kvantitativna analiza ocene rizika revidiranja, Oditor, Belgrade, Serbia, vol. 2, no. 3, pp. 21-38.

19. Tojnko, S., Rozman, Č., Unuk, T., Pažek, K., Pamič, S. (2011) A Qualitative Multi-Attribute Model for The Multifunctional Assessment of "Streuobst Stands" in NE Slovenia. Erwerbs-Obstbau, Vol. 53, No. 4, pp. 157-166.

20. Van Chuong, H. (2011): Land Suitability Analysis and Evaluation for Production of Fruit Trees Using GIS Technology. Journal of Science, Hue University, Vol. 67, No. 4A, pp. 13-22. 


\title{
VIŠEKRITERIJSKA ANALIZA VOĆNJAKA PREMA KONCEPTU INTEGRALNE PROIZVODNJE
}

\author{
Aleksandar Maksimovićc ${ }^{4}$ Zoran Grgič5, Ferhat Ćejvanovićc
}

\begin{abstract}
Sažetak
Integralna proizvodnja voća (IPV) je ekonomična i kvalitetna proizvodnja voća koja daje prioritet ekološko prihvatljivih sredstava za proizvodnju. Ona smanjuje nuspojave s ciljem da se poveća očuvanja okoline i zdravlja ljudi.
\end{abstract}

Prateći zahtjeve tržišta i povećanjem standarda proizvodnje, nametnuta je integrirana proizvodnja koja omogućava isplativosti, ravnopravno tržišno takmičenje i ekološko prihvatljivu proizvodnju poljoprivrednih proizvoda.

Uvođenje i provođenje modela višekriterijskog odlučivanja bazira se na DEXi metodom (višekriterijska analiza). Ova metoda omogućuje odabir najprimjerenijih voćne vrste za pokretanje proizvodnje voća. Ovaj model odlučivanja temelji se na ekspertskom mišljenju stručnjaka iz područja integrirane proizvodnje. Glavni kriterij u ocjenjivanju IPV prema DEXi modelu ekspertnog sistema su: ekonomski, tehnološki, ekološki i društveno-politički.

Rezultati višekriterijskog ekspertnog sistema DEXi pokazali su da je šljiva daje najbolje rezultate u skladu s integriranom konceptu proizvodnje i mogu se preporučiti kao prvi sadnog alternativu. Druga alternativa preporučuje jabuka, dok se treći preporučuje kruške.

Ključne riječi: Integralna proizvodnja voće, stručnjak za donošenje odluka, DEXi metoda, izbor voćne vrste, šljiva, jabuka, kruška.

4 Aleksandar Maksimović, doktorant, predavač, Visoka škola računarstva i poslvonih komunikacija eMPIRICA u Brčko distraiktu, Bulevara mira 4, Brčko district 76100, Bosna i Hercegovina, Telefon: +387 49230 111, E-mail: a.maksimovic22@gmail.com.

5 Redovni professor, dr Zoran Grgić, Univerzitet u Zagrebu, Poljoprivredni fakultet, Svetosimunska cesta 25, Zagreb, Hrvatska, Telefon: +385 012393760 E-mail: zgrgic@agr.hr.

6 Vanredni professor, dr Ferhat Ćejvanović, Univerzitet u Tuzli, Ekonomski fakultet u Tuzli, Univerzitetska Ulica br. 8, Tuzla, Bosna i Hercegovina i Vlada Brčko distrikta Bosne i Hercegovine, Bulevar mira br. 1, Brčko distrikt, Bosna i Hercegovina, Telefon: +387 35320 820, E-mail: ferhat.cejvanovic@gmail.com .

EP 2017 (64) 1 (69-79) 
ECONOMICS OF

AGRICULTURE

\section{CONTENT}

1. Željko Anđelković, Aleksandra Dragin, Sanja Božić, Kristina Košić

EMOTIONAL EXHAUSTION AND JOB SATISFACTION OF TOUR GUIDES IN RURAL AREAS . . . . . . . . . . . . . . 11

2. Sanja Đukić, Danica Glavaš-Trbić, Nikola Banjac

MANAGEMENT PROBLEMS OF RURAL DEVELOPMENT IN FRUŠKA GORA . . . . . . . . . . . . . . . . . . . . 27

3. Ivana Ilić, Bojan Krstić, Sonja Jovanović

ENVIRONMENTAL PERFORMANCES OF AGRICULTURE IN THE EUROPEAN UNION COUNTRIES . . . . . . . . . . . . . 41

4. Nataša Kljajić, Jonel Subić, Zorica Sredojević

PROFITABILITY OF RASPBERRY PRODUCTION

ON HOLDINGS IN THE TERRITORY OF ARILJE. . . . . . . . . . . 57

5. Aleksandar Maksimović, Zoran Grgić, Ferhat Ćejvanović

MULTI-ATTRIBUTE ANALYSIS OF ORCHARD ACCORDING

TO THE INTEGRATED PRODUCTION CONCEPT . . . . . . . . . . 69

6. Ozrislava Milinković, Branislav Jakić, Slobodan Vuksanović,

Dragana Macura, Milica Šelmić

MULTI- CRITERIA DECISION BASED APPROACH

TO SELECTING THE TYPE OF INDUSTRIAL HALLS

USED IN FOOD INDUSTRY $\ldots \ldots \ldots \ldots$. . . . . . . . . . 81

7. Gordana Nikić, Ljubiša Stamatović, Azra Sućeska

EMOTIONAL COMPETENCIES AND PERSONALITY

TRAITS OF MANAGERS IN MODERN AGROBUSINESS. . . . . . . .97

8. Vladimir Obradović, Nemanja Karapavlović

FINANCIAL REPORTING OF COMPREHENSIVE INCOME

IN THE FOOD AND BEVERAGE SECTOR

IN THE REPUBLIC OF SERBIA . . . . . . . . . . . . . . 113 
9. Aleksandar Ostojić, Nebojša Savić, Željko Vaško

CONSUMER ATTITUDES

ON BUYING FISH IN BANJA LUKA . . . . . . . . . . . . . . . 129

10. Radivoj Prodanović, Boris Kuzman, David Jovović, Lazar Ozegović

MARKET AND TRADE OF ORGANIC FRUITS IN SERBIA $\ldots . . .141$

11. Predrag Vukadinović, Aleksandar Damnjanović, Ljiljana Dimitrijević

ANALYSIS OF THE SALES AND INCOMES BETWEEN

DIFFERENT CATEGORIES OF AGRICULTURAL PRODUCTS . . . 157

12. Jugoslav Aničić, Svetlana Vukotić, Goran Maksimović

THE POSSIBILITIES AND LIMITATIONS

OF ENTREPRENEURSHIP DEVELOPMENT

IN AGRICULTURE IN SERBIA . . . . . . . . . . . . . . 171

13. Željko Bjelajac, Marijana Dukić - Mijatović, Joko Dragojlović

FOOD SAFETY AS ONE OF THE MAIN SAFETY $P$

REOCCUPATIONS OF A MODERN MAN . . . . . . . . . . . . . 191

14. Milan Bradić, Ljiljana Kosar, Lukrecija Djeri, Svetlana Vukosav, Vuk Garača

ECO-LABELLING OF ACCOMMODATION FACILITIES

AND ITS PERCEPTION BY RURAL TOURISTS:

CASE STUDY OF VOJVODINA . . . . . . . . . . . . . . 205

15. Vaso Jegdić, Iva Škrbić, Srđan Milošević

MODELS OF ENTREPRENURSHIP DEVELOPMENT

IN RURAL TOURISM DESTINATIONS IN VOJVODINA . . . . . . . 221

16. Duško Kuzović

MUSEUM OF VERNACULAR ARCHITECTURE OF WESTERN SERBIA

- Representative curtilages of the area surrounding middle

course of the river Drina and Podgorina . . . . . . . . . . . 239

17. Branko Mihailović, Zoran Simonović, Nikola Ćurčić

AGRICULTURAL RESOURCES AND DEVELOPMENT

PRIORITIES OF THE MUNICIPALITY OF STARA PAZOVA. . . . . 259

18. Radmilo Nikolić, Aleksandra Fedajev, Vidoje Stefanović, Silvana Ilić

THE AGRICULTURE SECTOR IN WESTERN BALKANS

- SOME CHARACTERISTICS OF DEVELOPMENT. . . . . . . . . . 275

19. Vladimir Njegomir, Rajko Tepavac, Nenad Ivanišević

ALTERNATIVE SOURCES OF FINANCING

ENTREPRENEURIAL UNDERTAKINGS IN AGRICULTURE . . . 295

Economics of Agriculture, Year 64, No. 1 (1-404) 2017, Belgrade 
20. Daniela Nuševa, Kristina Mijić, Dejan Jakšić

THE PERFORMANCES OF COFFEE PROCESSORS

AND COFFEE MARKET IN THE REPUBLIC OF SERBIA . . . . . . 307

21. Svetlana Roljević Nikolić, Predrag Vuković, Biljana Grujić

MEASURES TO SUPPORT THE DEVELOPMENT OF ORGANIC

FARMING IN THE EU AND SERBIA . . . . . . . . . . . . 323

22. ŽeljkoVojinović, Vera Zelenović, DragoCvijanović

PROGRAM OF STATE SUPPORT

TO AGRICULTURAL CREDITING. . . . . . . . . . . . . . . . 339

23. Nikola Vuksanović, Dragan Tešanović, Bojana Kalenjuk,

Milijanko Portić, Marija Knežević

SOCIO-DEMOGRAPHIC CHARACTERISTICS

AS DETERMINANTS OF DIFFERENCES

IN PERCEPTION OF LOCAL GASTRONOMY . . . . . . . . . . . . 359 